\title{
TERRITORIAL UNCERTAINTY OF PODLASIE REGION. REGIONAL IDENTITY VS. ADMINISTRATIVE DIVISION
}

\author{
Michał Konopski \\ Institute of Geography and Spatial Organization \\ Polish Academy of Sciences \\ Twarda 51/55, 00-818 Warsaw: Poland \\ konopski@twarda.pan.pl
}

\begin{abstract}
The essence of the research problem stems from the observed dichotomy between names given to voivodships (provinces) as a result of administrative reform of 1999 and traditional names of historical regions. The paper examines the issue of territorial uncertainty of Podlasie, a historical and cultural region situated in eastern Poland. Such uncertainty has been observed in terms of inhabitants' territorial identity expressed via names given to regional companies, institutions and media confronted with historical borders of the region. The recent Poland's administrative reform of 1999 has contributed to discrepancy in perceiving the region of Podlasie and has resulted in its pronounced identification with the Podlaskie Voivodship. Spatial analysis concerning distribution of companies and institutions, whose names refer to this region conducted for the years 1983-2013 has proven that Podlasie is increasingly identified with contemporary Podlaskie Voivodship. On the other hand, names of regional media reveal stronger regional identification with Podlasie within its historical borders rather than contemporary Podlaskie Voivodship. Current administrative division contributes to developing new territorial identity or changing the spatial range of territory inhabitants identify themselves. Moreover, this process also potentially leads to the deepening of territorial uncertainty within society and may result in weakening people's attachment to the place of living and community's social bonds.
\end{abstract}

Keywords: Podlasie, Podlaskie Voivodship, territorial uncertainty, regional identity, administrative division, names of institutions and companies, regional media.

\section{Introduction}

The subject of this study concerns territorial identity, understood as self-identification of humanbeings with a certain area, which they are willing to perceive as part of their existence (Szczepanski 1972). Crucial elements in determining territorial identity include existence of emotional bonds with the territory, the landscape, but also with the people living in this area (territorial group, community) along with products of material and spiritual culture as well as symbols assigned to given territory (Szul 1991). There have developed several approaches towards territorial identity. Firstly, at personal level (by Szczepański 2003) there can be distinguished psychological approach, where the key element is the degree of individual identification with the region, its society and culture. The sociological approach focuses on separation functioning in collective consciousness into: us and them and a sense of distinctness. On the other hand, in ethnographic approach the most important 
determinant of identity become such components as traditions and awareness of cultural heritage. In historical approach, identity is understood by individual and social relation with the history of region, its heroes and historical institutions. Economic approach assumes that common managing e.g. regional economy, inter-regional co-operation and competition are important elements fostering preservation or decomposition of territorial identity. Regarding assumptions of this study, the most interesting appears to be the geographical approach towards territorial identity, in which the key issue is the analysis of people's relation with the territory, or more precisely attachment to place and space. In case when such attachment is vague, ambiguous - or not collectively shared - one may speak of territorial uncertainty, which is also the subject of this study.

Further focusing on the geographical approach, territorial identity can be shaped on several spatial levels. Rykiel (1999) distinguishes five hierarchical levels: elementary (home, family), local (neighborhood, district), regional (region, regional collectivity), national (country, nation) and supranational (e.g. Europe, the European Union). Considering that the research area of this study is Podlasie, it is anticipated that local and regional are the dominating spatial levels of territorial identity in this case. However, the author assumes that taking into account historical background - a sense of regional identity understood in the context of a common Podlasie region is weaker than in the case of other Polish regions with strongly developed identities like Silesia, Wielkopolska, Podhale or Kashubia. Hypothetically, in Podlasie there might be however a strong sense of national identity due to significant share of different ethnic groups.

\section{Podlasie - a borderland region}

The examined research area is Podlasie, understood as a historical and cultural borderland region located in eastern Poland. However, perception of Podlasie undergoes dynamic changes, hence decision to undertake this topic. Determining the spatial range of this region is a complex task because this area has historically been characterized by considerable variability of state and administrative borders. Moreover, there are no explicit environmental components that would allow for unambiguous physico-geographical delimitation. As a result, Podlasie is often perceived as a mélange of various concepts, including geographical, historical, ethnographical and others, therefore delimitation of this region is challenging and ambiguous (Kaczmarek 1980). Defining Podlasie, like other borderland areas demonstrating a number of transitional qualities is difficult (Plit 2008). Considering the physicogeographical point of view, this is not a clearly defined region. Pietkiewicz (1962) by distinguishing the Mazowiecko-Podlaska Lowland expressed strong relation between the geographical regions of Mazowsze (Mazovia) and Podlasie while the latter is not an independent region. Kondracki (1978) recognized the Południowopodlaska (Southern Podlasie) Lowland as one of sub-provinces within the Środkowopolskie (Mid-Poland) Lowlands, while the Północnopodlaska (Northern Podlasie) Lowland has been designated as a sub-province of the Podlasko-Białoruskie (Podlasie-Belarus) Uplands. The Bug river acts as a natural border between these units, being (according to Kondracki 1978) at the same time border between the macro-regions of Central and Eastern European Lowlands. On the other hand, Dylikowa (1973), designated a single, compact region of Podlasie, suggesting its southern border on the Krzna river, at the same time emphasizing the central position of the middle Bug river basin. The key role of a river basin area in developing a cultural region has been proposed by A. Piskozub (1987). 
The historical past of Podlasie has highly contributed to its ethnical, religious, linguistic - and consequently -cultural diversity. Today, it is one of the most diverse Polish regions in this respect (Barwiński 2004). In this area many cultures have clashed for centuries. One can speak of several steps that shaped Podlasie over time:

1) Initially Podlasie referred to the territory by middle course of the Bug river, a forested area separating three main ethnic groups of Western Slavs, Eastern Slavs and Balts (Michaluk 2013). It was a strip of demarcating forests between Mazowsze (Mazovia) and Ruthenia located between the rivers of: Biebrza, Narew, Bug and Krzna (Dobroński 2013 after Gloger 1903). The first settlers originated from the neighboring areas.

2) In 1513 the area of Podlasie was formally recognized as an administrative unit - Podlaskie Voivodship (province), with its capital city in Drohiczyn located by the Bug river, the province was partially covering territory of present-day Belarus. In 1566, as a result of administrative reform the Podlaskie Voivodship was re-established (Fig. 1), all of which is included in today's Polish territory. The borders of this administrative units did not change until the third partition of Poland in1795. This was - so far - the longest period of more than two hundred years of stable administrative borders of Podlaskie Voivodship.

3) Partitions of Poland (1795-1918) have broken the territorial integrity of Podlasie up to present day. Importantly, the Bug river, which for centuries acted as a regional development axis (e.g. through communication function) has become henceforth a political or administrative border dividing historical Podlaskie Voivodship (Michaluk 2013). The period of partitions had a significant impact on the perception of Podlasie. In 1810, the Department of Siedlce was established including both historical areas of Podlasie south of the Bug river, but also large parts of the former Lubelskie Voivodship. Soon, this unit was commonly described as the "Podlaskie Voivodship." In 1837 the Siedlce Governorate was established covering the same area, but its commonly functioning name was the Governorate of Podlasie (Michaluk 2013). It is worth noting that its borders to a very high extent overlap with the current borders of the Roman Catholic Diocese of Siedlce. This might prove the continuity of historical borders to present day. In the 19th century, due to the fact that Siedlce was the capital city of the governorate it began to be identified with the region of Podlasie. However, historically, Siedlce was a town in north-eastern reaches of Małopolska region (Zaborowski 2013). In times of Governorate of Podlasie, the Podlasie region started to be identified only with the areas located to the south of the Bug river (Michaluk 2013) while the area located on the northern river bank was referred to as the "Ruthenian Podlasie". Perception of spatial range of Podlasie region was also affected by the cult of the so-called Martyrs of Podlasie - thirteen Greek Catholic Church followers shot in 1874 the by tsarist troops in Pratulin village - located within the borders of the former Governorate of Podlasie.

4) In the days of the Second Republic of Poland the Podlaskie Voivodship was not re-established, the historical region of Podlasie was again divided by the Bug river into Białostockie and Lubelskie Voivodships.

5) The administrative reform of 1975 turned out to be significant for the perception of Podlasie as area of the historical Podlaskie Voivodship was divided into five small provinces. One of them - Biała Podlaska Voivodship, which name primarily referred to its capital city (Biała Podlaska) was quite commonly identified with the historical and cultural region of Podlasie. In contrast, the area located north of the Bug river was commonly perceived as the "Białystok region".

6) Contemporary Podlaskie Voivodship established as a result of the administrative reform of 1999. The name of this territorial unit suggests a recreation of historical Podlaskie Voivodship (1566- 
1795), which is only partly the case. A newly formed province has been created entirely from the former Białostockie Voivodship (existing in 1975-1999), almost entire Łomżyńkie Voivodship (except for five western municipalities) and the eastern part of the Suwalskie Voivodship including the city of Suwałki. Thus, only territories located north of the Bug river have been considered as the Podlaskie Voivodship.

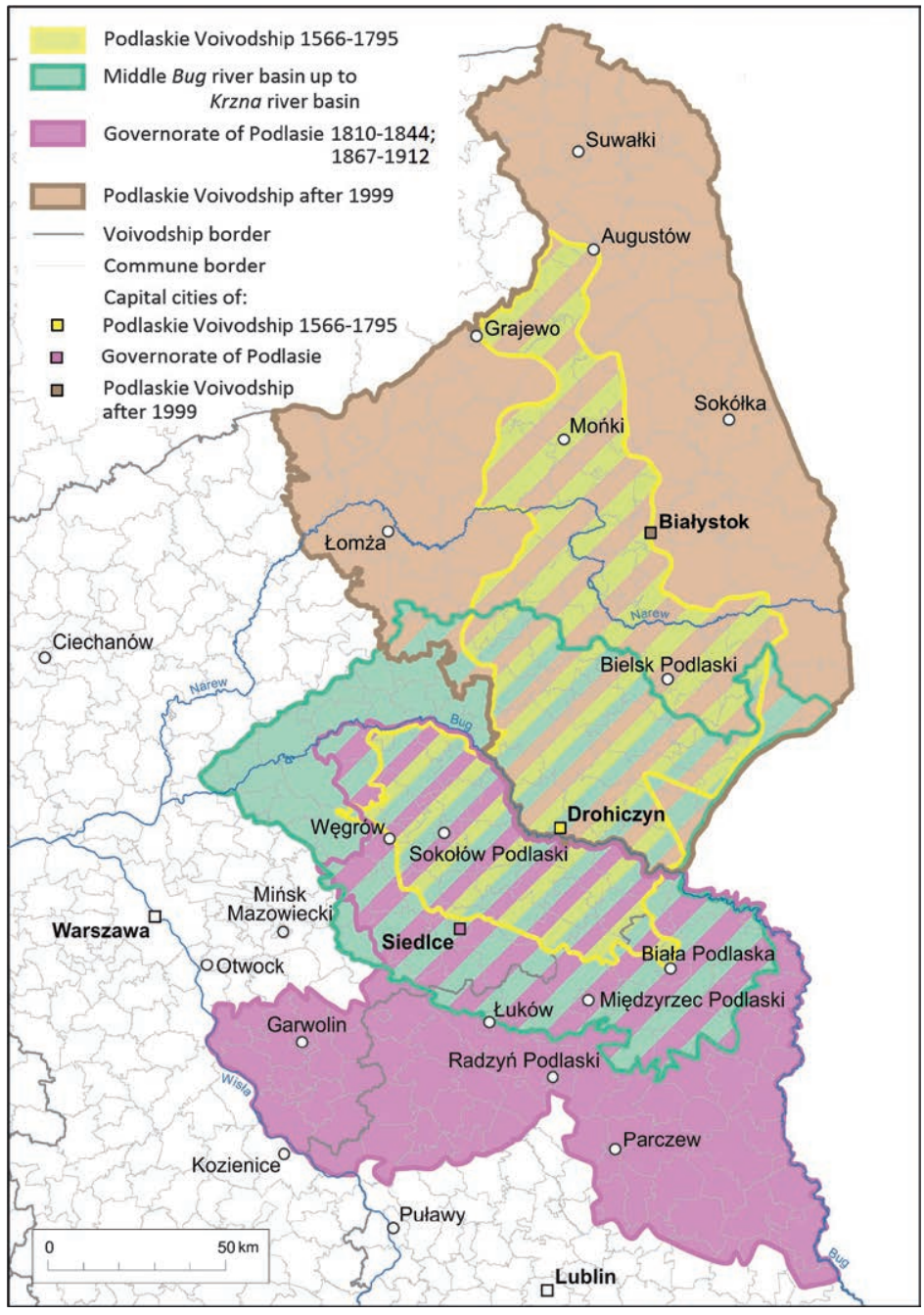

Figure 1. Territorial changes of the Podlaskie Voivodship in the period 1566-1999 and the area of middle Bug river basin

\section{The new Podlaskie Voivodship}

The current administrative division of the country, which in its assumptions adapts Poland to the principles of regionalization used in the European Union was criticized even before it came into force 
in 1999. Miszczuk (2003) highlights that the current division differs from all concepts presented by the scientific community.

The essence of the research problem stems from the observed dichotomy between names given to newly formed voivodships as a result of recent administrative reform of 1999 and traditional names of historical regions. Among the newly established sixteen provinces there is, in fact, Podlaskie Voivodship, with its capital city in Białystok. However, this administrative unit includes only northern part of the historical Podlaskie Voivodship (1566-1795). Other parts - south of the Bug river- have been incorporated by the Mazowieckie and Lubelskie Voivodships. The new administrative unit (Podlaskie Voivodship) in its territory, however, includes areas that historically or culturally have never been associated with Podlasie - such as Suwałki region as well as longitudinally located belt of territories south to Hajnówka - historically associated with the Grand Duchy of Lithuania - and Łomża region in the west, historically associated with Mazovia.

The current administrative division appears to be highly debatable already on the basis of the names of cities that have been included in the new units. For example, Sokołów Podlaski is located in the Mazowieckie Voivodship, whereas Wysokie Mazowieckie in Podlaskie Voivodship. On the other hand, the cities of Radzyń Podlaski, Międzyrzec Podlaski and Biała Podlaska are currently located in the Lubelskie Voivodship. Similar discrepancies between new administrative units and historical regions can also be found in other provinces. An interesting comparative analysis on borders of all contemporary provinces and historical regions was conducted by Zaborowski (2013). The author of this study focuses his research on Podlasie based on observation that perception of this region - not just from the viewpoint of local population - has changed to the greatest extent among the newly established provinces.

\section{Perception of Podlasie}

The new image of Podlasie, identified with the current Podlaskie Voivodship has been continually perpetuated in the social consciousness since 1999. Such situation can be caused by several factors. Firstly, this may result from lack of knowledge concerning historical borders of Podlasie presented by both autochthons and outsiders. Secondly, the widespread identification of region's name with voivodship's name can be caused by the so-called mental shortcut - Podlasie being a shorter word is more comfortable and easier to operate with. Podlasie has become a common synonym for the Podlaskie Voivodship in media - for example, during a television weather forecast - presenter talks about expected lowest air temperatures in Podlasie while at the same time pointing at Suwałki region. One of television advertisement talks about a dreamt house by the lake in Podlasie situated in a typical early post-glacial landscape, which would never be found in historical region. The authorities of the Podlaskie Voivodship commonly use the term Podlasie as a synonym for the administrative unit - even their website has been entitled Gate to Podlasie (Wrota Podlasia) referring to the observed mental shortcut.

A similar trend can also be seen in case of scientific community. For instance - M. Zdrodowska (2007) in her work Common image of Podlasie - a strategy for creating regional image (Potoczny obraz Podlasia - strategia kreowania wizerunku regionu) comprises analysis concerning the image of Podlasie outlined in the official materials of Podlaskie Voivodship authorities, tourist guides, photo albums, scientific texts and even films. When considering these sources, the author does not refer to Podlasie as a cultural and historical region, but clearly associates Podlasie with the current 
Podlaskie Voivodship. Interestingly, M. Zdrodowska does not come from Podlasie, thus she presents an outsider approach to this region. There are many similar cases of implementing the term Podlasie in the context of administrative unit. Another interesting example can be the collective work led by A. F. Bocian Podlasie as the region of future (2009) (Podlasie regionem przyszłości), which contains a number of scientific papers on social and economic issues, in which Podlasie and the Podlaskie Voivodship are commonly used as synonyms. It is worth noting that both these works have been published by the University of Białystok, and most authors of Podlasie as the region of future are its employees. It can therefore be concluded that contemporary perception of Podlasie is not clear - whether this term refers to cultural and historical region or administrative unit. This uncertainty is shared by both autochthons and outsiders. Thus, a significant question arises concerning the spatial range of territory, with which the region's inhabitants identify themselves.

\section{Spatial analysis of companies and institutions for the years 1983-2013}

In order to verify the relevance of undertaking this research subject, there has been conducted an analysis of territorial identity of Podlasie confronting with the existing and previous (before 1999) administrative units. This research method is imperfect and should be considered only as a basic analysis tool. It has been adopted due to the simplicity of application and data availability. For the purpose of this study, it has been assumed that potential territorial identity can be manifested in the names of companies and institutions. Therefore a database of such entities has been compiled - whose names refer to the region of Podlasie and the Podlaskie Voivodship. The database included location and number of companies and institutions whose names contain elements: Podlaski, Podlaska, Podlaskie in 1983, 1993, 2003 and 2013. The data source consisted of telephone books for 6 provinces for the years 1983 and 1993 and three provinces for 2003 (after the administrative reform). For 2013 an available Internet database was used. The assumed time period (1983-2013) allows to observe the studied phenomenon in a dynamic approach, taking into account the very important factor of administrative reform in 1999. In the period between 1983 to 2013 (Fig. 2) there is an immense increase in the number of companies and institutions, whose names refer to Podlasie or the Podlaskie Voivodship. During these 30 years the overall number of such entities increased by over $900 \%$ (from 34 to 314 ).

Before the administrative reform $(1983,1993)$ the vast majority of these entities were located in the area of historical Podlaskie Voivodship (1566-1795) and Governorate of Podlasie (Fig. 2). This may prove a hypothetical continuity of identification with the historical region. In 1983 there were 34 of such entities and 44 in 1993 thus a potential factor of enhancing entrepreneurship caused by political transformation in Poland has not been that evident.

After the administrative reform, there have been established numerous such entities in the new Podlaskie Voivodship, including areas historically unrelated to Podlasie. Between years 1993 and 2003 the number of such entities increased greatly (from 44 to 188). A key role in this process is played by the administrative capital city of Białystok (Fig. 3), in which majority of such companies and institutions were established. It is important in case of names of the new institutions derived from the Podlaskie Voivodship that this is an effect of administrative requirement and not a manifestation of territorial identity as in years 1983 and 1993. For instance, in the year $200380.3 \%$ (151 of 188) of all analyzed companies/institutions with names referring to Podlasie region were labeled as a result 
of administrative requirement. In 2013 the overall number of examined companies and institutions rose up to the sum of 314 , while $66.9 \%$ (210) of them resulted from the mentioned administrative requirement. Once again, the highest increase was observed in Białystok, and in the Podlaskie Voivodship. However, there also can be observed a slight increase in number of such entities in contemporary Mazowieckie and Lubelskie Voivodships as well as the number of locations (from 9 to 14). These are particularly interesting cases as they potentially manifest territorial identity with Podlasie region opposed to Podlaskie Voivodship.
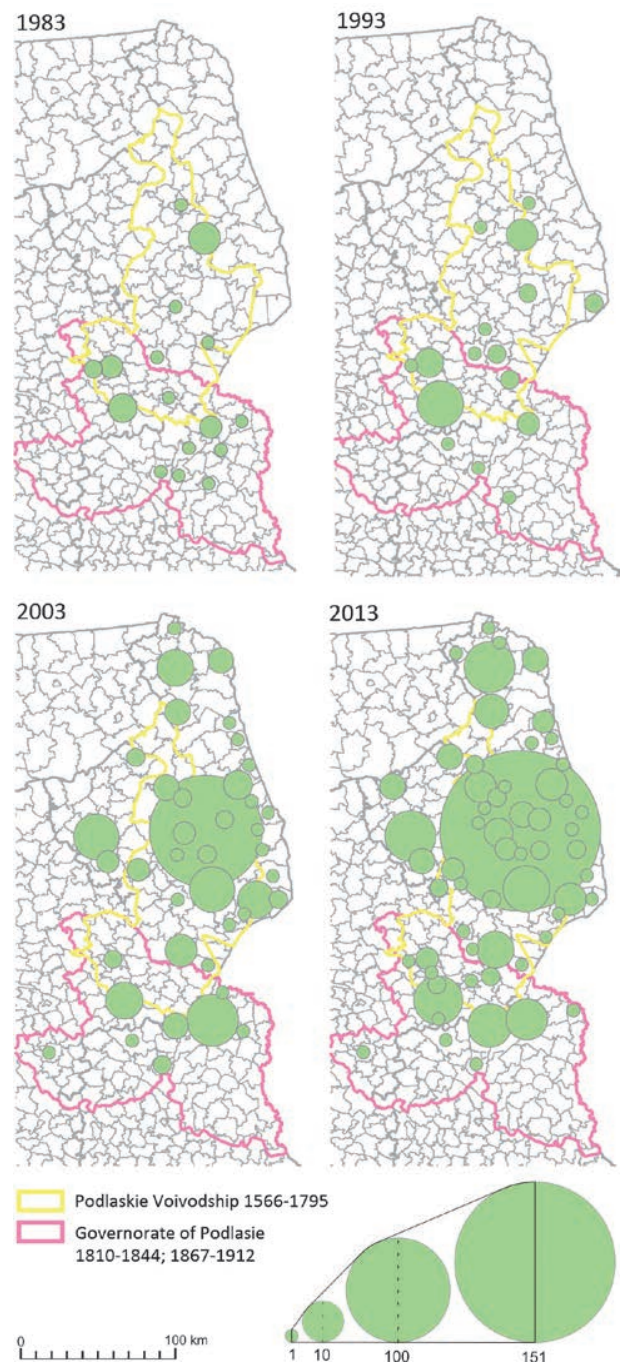

Figure 2. Spatial distribution and number of companies and institutions whose names refer to Podlasie in 1983, 1993, 2003 and 2013

\section{Biała Podlaska}

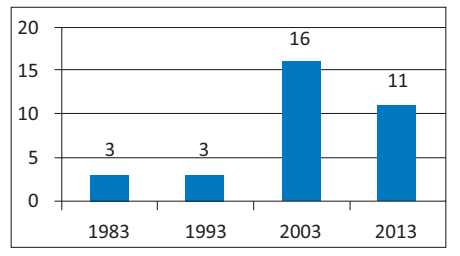

Białystok

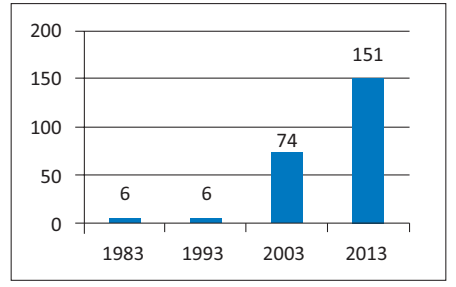

\section{Siedlce}

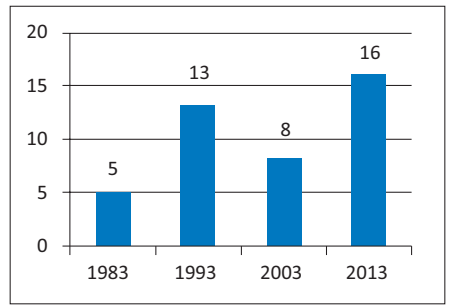

\section{Suwałki}

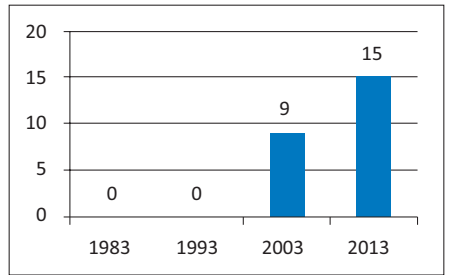

Figure 3. Number of companies and institutions whose names refer to Podlasie in 1983, 1993, 2003 and 2013 in selected cities 


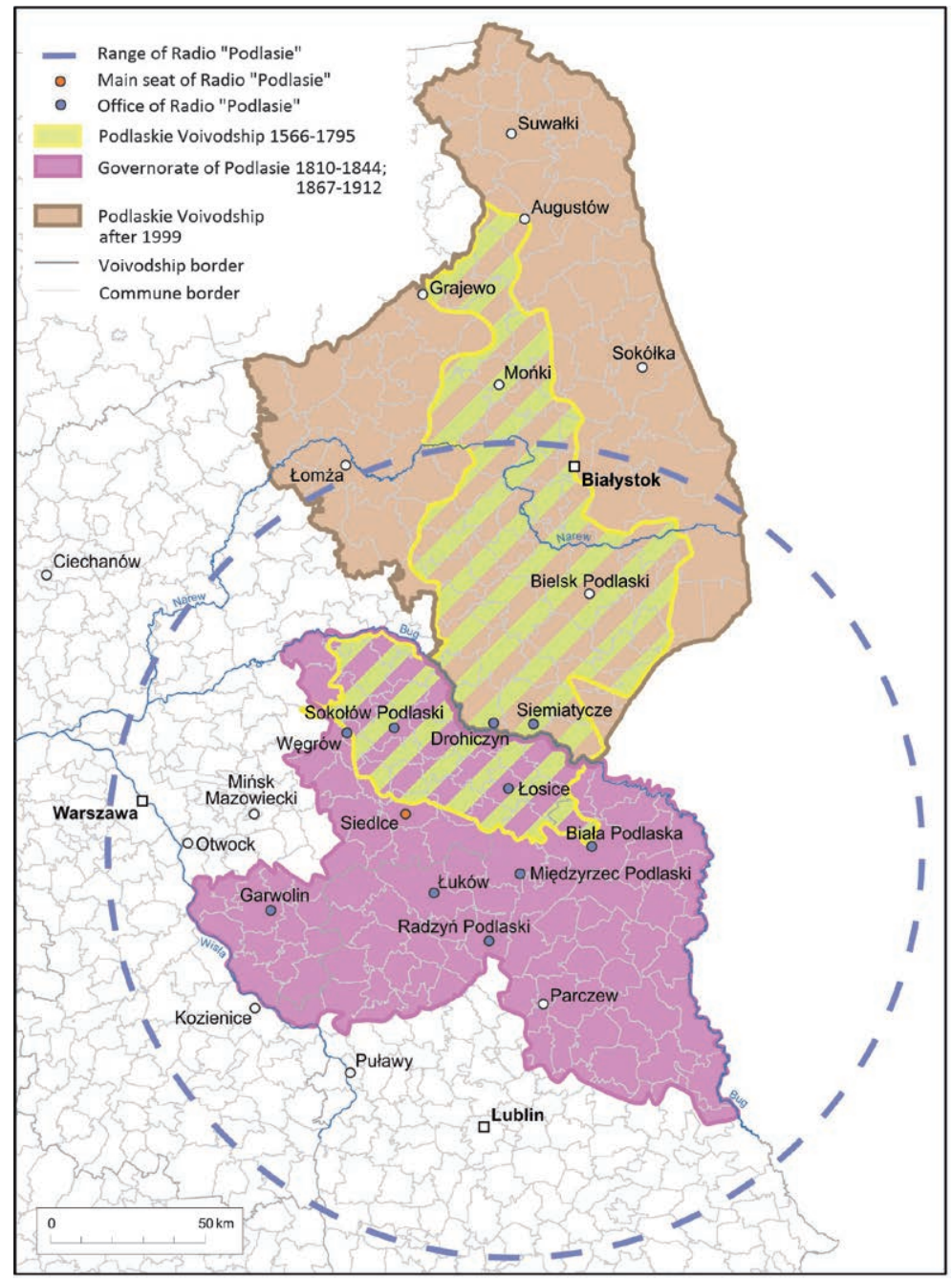

Figure 4. Spatial range of "Podlasie" Radio station frequency, location of main seat and offices

The second part of research considered media as potential manifestation of territorial identity with Podlasie (Fig. 4). Spatial analysis of the range of "Podlasie" radio leads to similar conclusions as for the names given to companies and institutions. Namely, there is low spatial coherence between the territory named Podlaskie Voivodship and Podlasie as region, with which population identifies.

First of all, there is only one radio station, whose name refers to Podlasie and its seat is not located in contemporary Podlaskie Voivodship. The main seat of the radio station is located in Siedlce - the capital city of the former Governorate of Podlasie, currently in the Mazowieckie Voivodship. Majority of radio offices are situated within the borders of Governorate of Podlasie or Podlaskie Voivodship (1566-1795) - south of the Bug river and only two offices can be found in contemporary Podlaskie Voivodship. Interestingly, the radio's seat and the its offices in great majority (apart from Radzyń Podlaski) located within the middle Bug river basin (Fig.1). This fact would be a prove supporting the hypothesis of A. Piskozub (1987), who emphasized the key role of 
a river basin area in developing a cultural region, in this case Podlasie. Perhaps the true territorial identity (unaffected by administrative regulations) is still to a certain extent associated with this environmental factor.

In the case of regional press inconsistency between the borders of current administrative unit and potential territorial identity seems to be even deeper (Fig.5). The editorial offices of "Tygodnik Podlaski" (Podlasie Weekly) and "Słowo Podlasia" (The Word of Podlasie) are both located in the town of Biała Podlaska. The newspaper offices are located in the historical Podlaskie Voivodship or Governorate of Podlasie, but only south of the Bug river. These observations potentially suggest higher level of territorial identity with Podlasie in parts of the Mazowieckie and Lubelskie Voivodships than in actual Podlaskie Voivodship. The titles of regional press in the latter do not relate directly to Podlasie region, they rather take the local name e.g. "Głos Siemiatycz" (Siemiatycze Voice) or "Tygodnik Suwalski" (Suwatki Weekly) thus indicating the dominance of local identity.

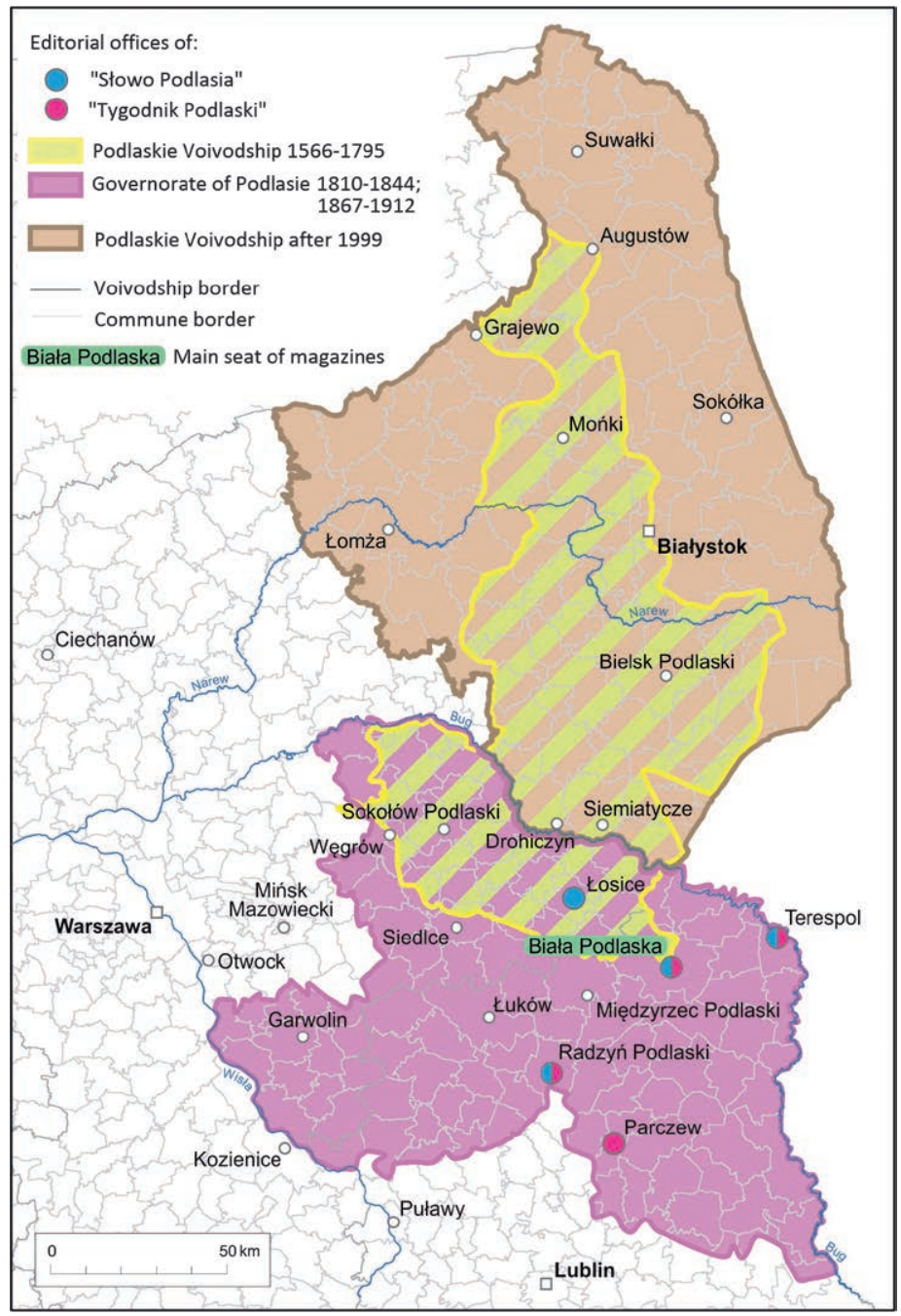

Figure 5. Spatial distribution of regional press titles whose names refer to Podlasie 
By analyzing the distribution of press titles, one may state that the hypothetical factor shaping contemporary territorial identity of the middle Bug river basin is also relevant, but in this case two newspaper offices are located outside this area (in Radzyń Podlaski and Parczew). More convincing would another factor, namely that there might be the highest territorial identity with Podlasie within the borders of former Governorate of Podlasie. Interestingly, all the editorial offices and main seat of magazines are located within the area of fomer Biała Podlaska Voivodship (1975-1999), suggesting that perhaps these titles not necessarily refer to Podlasie but to the region of Biała Podlaska.

\section{Conclusion}

One must take into consideration that methods, which have been applied for the purpose of this research do not allow for explicit determination of regional identity associated with Podlasie. They only outline the essence of research problem in a preliminary manner. Majority of names given to companies and institutions in the contemporary Podlaskie Voivodship are in majority result of administrative regulations. On the other hand, labeling a particular entity located in the Mazowieckie and Lubelskie Voivodships with a name referring to Podlasie can be considered as a manifestation of territorial identity. Similarly, naming a radio station "Podlasie" with its seat in the Mazowieckie Voivodship suggests a possible identification with a historical region rather than administrative unit.

Applied methods are sufficiently precise to conclude that there is a clear territorial uncertainty of population inhabiting the examined area - at the same time showing weakness of the current administrative division in Poland. Contemporary Podlaskie Voivodship is characterized by low coherence (both in territorial and social terms) with the historical and cultural Podlasie region. The historical borders still to some extent define the territory, with which people identify themselves, although they do not exist for centuries. The author of this study is fully aware that determining the actual factors shaping today's territorial identity with Podlasie requires more sophisticated research methods, mainly surveys.

Current administrative division may potentially contribute to developing new territorial identity or changing the spatial range of region, that society identifies with. Especially younger group of population is vulnerable to these processes, which over time contribute to the deepening of territorial uncertainty. This, in turn may lead to disturbance of territorial and social cohesion. The result might be weakening of people's attachment to the place of living and community's social bonds. Moreover, territorial identity is linked to local development processes, including a number of social values, quality and efficiency of local politics, social creativity and brand of place. Raszkowski (2014) draws attention to the growing importance of territorial identity in programming new paths for local development. Local population by identifying with the territory develops a civic society in a more conscious way. On the contrary, a deepening territorial uncertainty leads to adverse, undesired processes. 


\section{References}

Barwiński M., 2004. Podlasie jako pogranicze narodowościowo-wyznaniowe, Łódź: Wydawnictwo Uniwersytetu Łódzkiego.

Bocian A.F. (ed.), 2009. Podlasie regionem przyszłości, Białystok: Wydawnictwo Uniwersytetu w Białymstoku.

Dobroński A., 2013. Obraz historyczny Podlasia. Pytania badawcze [in:] Podlasie nadbużańskie. 500-lecie województwa podlaskiego, Muzeum Rolnictwa im. ks. Krzysztofa Kluka. Instytucja Kultury Województwa Podlaskiego, Urząd Marszałkowski Województwa Podlaskiego, Departament Kultury i Dziedzictwa Narodowego.

Dylikowa A., 1973. Krainy geograficzne, Warszawa: Państwowe Zakłady Wydawnictw Szkolnych.

Gloger Z., 1903. Kraków: Geografia historyczna dawnej Polski.

Kaczmarek J., 1980. Na Podlasiu. Gawędy krajoznawcze, Warszawa: Wydawnictwo Szkolne i Pedagogiczne.

Kondracki J., 1978. Geografia fizyczna Polski, Warszawa: PWN.

Michaluk D., 2013. Granice województwa podlaskiego i postrzeganie obszaru Podlasia w latach 1513-2013 [in:] Podlasie nadbużańskie. 500-lecie województwa podlaskiego, Muzeum Rolnictwa im. ks. Krzysztofa Kluka. Instytucja Kultury Województwa Podlaskiego, Urząd Marszałkowski Województwa Podlaskiego, Departament Kultury i Dziedzictwa Narodowego

Miszczuk A., 2003. Regionalizacja administracyjna III Rzeczpospolitej. Koncepcje teoretyczne a rzeczywistość, Lublin: Wydawnictwo Uniwersytetu Marii Curie-Sklodowskiej.

Pietkiewicz S., 1962. Podstawy fizjograficzne województwa podlaskiego [in:] Podstawy rozwoju województwa białostockiego. Materiały z konferencji naukowej IG PAN cz. 1, Białtystok.

Piskozub A., 1987. Dziedzictwo polskiej przestrzeni. Geograficzno-historyczne podstawy struktur przestrzennych ziem polskich, Wrocław: Zakład Narodowy im. Ossolińskich.

Plit F., 2008. Województwo Podlaskie - region pogranicza [in:] Dokumentacja Geograficzna, Warszawa: Wydawnictwa Uniwersytetu Warszawskiego, vol. 36, pp. 7-14.

Raszkowski A., 2014. Tożsamość terytorialna w odniesieniu do rozwoju lokalnego, Prace Naukowe Uniwersytetu Ekonomicznego we Wrocławiu, vol. 332, Wrocław.

Rykiel Z., 1999. Przemiany struktury społeczno-przestrzennej miasta polskiego a świadomość terytorialna jego mieszkańców. Prace Geograficzne, vol. 170, Warszawa: IGiPZ PAN.

Szczepański J., 1972. Elementarne pojęcia socjologiczne, Warszawa: PWN.

Szczepański M.S., 2003. Tożsamość regionalna - w kręgu pojęć podstawowych i metodologii badań. Między tożsamościq indywidualnq a społecznq - preliminaria.

Szul R., 1991. Przestrzeń, Gospodarka, Państwo. Uniwersytet Warszawski, Warszawa: Europejski Instytut Rozwoju Regionalnego i Lokalnego.

Zaborowski Ł., 2013. Podział kraju na województwa. Próba obiektywizacji, Warszawa: Wydawnictwo Naukowe Scholar.

Zdrodowska M., 2007. Potoczny obraz Podlasia - strategia kreowania wizerunku regionu [in:] Pogranicze. Studia Społeczne. Tom XIII, Białystok: Wydawnictwo Uniwersytetu w Białymstoku.

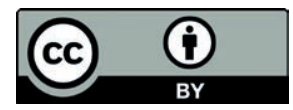


http://rcin.org.pl 